\title{
ICТОРИЧНЕ КРАСЗНАВСТВО
}

УДК 94(477.83/.86):070 “1889/1914”

\section{ДІЯЛЬНІСТЬ ФІЛІЇ ТОВАРИСТВА "ПРОСВІТА" У М. КОЛОМИЯ НАПРИКІНЦІ ХІХ - НА ПОЧАТКУ ХХ ст.}

\author{
Андрій КОРОЛЬКО \\ Державний вищий навчальний заклад \\ "Прикарпатський національний університет імені Василя Стефаника", \\ кафедра історії Украӥни і методики викладання історії, \\ вул. Шевченка, 57, 76018, Івано-Франківськ, Україна \\ DOI: 10.15330/gal.33.93-112 \\ e-mail: korolko_andr@ukr.net \\ ORCID: 0000-0001-7435-5806
}

У статті досліджується діяльність філії товариства “Просвіта” у м. Коломия наприкіниі ХІХ - на початку XX cm. Проаналізовано статути “Просвіти” щзодо організації діяльності філій $i$ читалень культурно-просвітницького товариства. Простежено форми роботи і практичні кроки діяльності філіі “Просвіти” в м. Коломия у досліджуваний період. Звернуто увагу на труднощі у роботі осередку товариства у зв'язку з діяльністю читалень Товариства імені М. Качковського та “Коломийського товариства "Народних спілок”", які знаходилися у фарватері впливу москвофілів та радикалів. Висвітлено діяльність двох читалень “Просвіти” у м. Коломия - на “кутському передмісті” та ім. Тараса Шевченка. Відзначається, щзо філія “Просвіти” наприкінці XIX-на початку XX ст. стала основним засобом впливу на суспільну думку та підняття культурного рівня жителів краю. Їі члени виявляли в міському $i$ сільському середовищі людей, здатних до розумової прачі, залучали до суспільно-політичної діяльності $з$ перетворенням у подальшому на провідників української нації.

Ключові слова: філія, “Просвіта”, читальня, Покуття, культурно-просвітницька робота, бібліотека.

Заснована в 1868 р. громадська організація “Просвіта" ставила за мету посилення культурного розвитку та піднесення національної свідомості українського народу. 3 початком XX ст. "Просвіта" поширила діяльність на всі українські землі. Створена в останній чверті XIX ст. організаційна структура на місцях (філія - читальні) підпорядковувалася головному осередку товариства у м. Львів. Саме на філії "Просвіти" в умовах політизації національного руху покладалася велика надія в культурному пробудженні українців Австро-Угорської імперії.

Мета статті - комплексне дослідження діяльності філії товариства "Просвіта" у м. Коломия наприкінці XIX - на початку XX ст. Ї̈̈ досягнення передбачає вирішення таких завдань: проаналізувати статути “Просвіти” щодо організації діяльності філій і читалень культурнопросвітницького товариства; простежити форми і практичні кроки філії “Просвіти” в м. Коломия у досліджуваний період; звернути увагу на труднощі у роботі осередку товариства у зв'язку з діяльністю читалень Товариства імені М. Качковського та "Коломийського товариства "Народних спілок”, які знаходилися у фарватері впливу москвофілів та радикалів; висвітлити діяльність двох читалень “Просвіти” у м. Коломия - на “кутському передмісті" та імені Тараса Шевченка.

Аналіз останніх досліджень. Ця проблема ще не стала предметом вивчення в історіографії. Окремі аспекти 3 досліджуваної проблеми знайшли своє відображення в наукових працях дослідників П. Арсенича ${ }^{1}$, В. Бойцана 2 , Р. Гарата ${ }^{3}$, I. Зуляка ${ }^{4}$, I. Монолатія ${ }^{5}$, А. Середяк ${ }^{6}$ та автора статті ${ }^{7}$

\footnotetext{
1 Арсенич П. Філія “Просвіти” в Коломиї. Бюлетень Івано-Франківського ОО ВУТ “Просвіта" ім. Т. Шевченка. 1997. № 10. С. 7.

${ }^{2}$ Бойцан В. Читальня. Енц̧иклопедія Коломийщчини. Зшиток 12, літера Ч. Коломия : Вік, 2001. С. $38-45$.
} 
Важливим джерелом для вивчення проблеми $є$ неопубліковані матеріали, які зберігаються у Центральному державному історичному архіві України у м. Львів. Нами опрацьовано окремі архівні справи фонду 348 “Товариство "Просвіта", м. Львів", зокрема листування, протоколи зборів, списки, звіти та різні документи про діяльність філії “Просвіти” у м. Коломия, а також читалень товариства на “кутському передмісті” та імені Тараса Шевченка

Ще одна група використаних джерел - українські часописи кінця XIX - початку XX ст. (“Діло”, “Батьківщина”, “Свобода”, “Читальня. Письмо з Просвіти”, “Ілюстрований калєндар товариства "Просвіта"). Тогочасна газетно-журнальна періодика пильну увагу приділяла культурно-просвітницькому становищу українців в Східній Галичині. Часописи друкували звіти про діяльність товариства, представлені й обговорені на щорічних загальних зборах чи спеціальних нарадах. Вони ознайомлювали загал із даними про кількість членів філій і читалень, змінами керівного складу інституції, пропозиції щодо корегування окремих статутних положень, із розвитком відносин з іншими українськими товариствами, заснування при читальнях крамниць і позичкових кас, видавничою діяльністю тощо. На сторінках тогочасних часописів у рубриках "Новинки", "Новини”, "Новинки і всячина", "Всячина і новинки", "Письма 3 краю", "Вісті 3 краю”, "Рух в руських товариствах", "Рух політичний, просвітний і економічний руського народу”, “Вісті просвітні”, “Дописи Діла”, “Дописи”, “Обходи в пам’ять Т. Шевченка”, “3 ювілейних обходів у краї”, “Конкурси бурс”, “Конкурси бурс і інститутів”, “Оповістки” в різних за змістом і за формою статтях подавалася інформація про діяльність філії "Просвіти" в м. Коломия, читалень Коломийського філіального округу. Загалом, джерелознавча цінність публікацій періодики досліджуваного періодики полягає в тому, що тут поміщувалися доволі цінні інформативні матеріали 3 питань культурно-просвітницького та громадського життя краю, практичної праці осередків "Просвіти" на місцях.

Діяльність товариства "Просвіта" від часу заснування в 1868 р. до початку Першої світової війни регулювалася статутами 1868, 1873, 1876, 1891, 1906 рр. Перший статут надавав "Просвіті" характер наукового товариства, яке мало за мету не тільки ширити просвітні ідеї серед українського народу, але й пізнавати, збирати й видавати твори народної словесності тощо. Другий статут 1873 р. обмежив діяльність товариства через поширення просвіти серед народу. До 1876 р. "Просвіта" займалася не тільки виданням популярних книжечок для народу, але й сприяло виходу у світ шкільних підручників для руських (українських) гімназій. Статут 1876 р. відкрив дорогу для членства в товаристві не тільки для інтелігенції, але й для селян. Головним завданням нового статуту $1891 \mathrm{p}$. стало поширення просвіти серед всіх верств

\footnotetext{
${ }^{3}$ Гарат Р. М. Філія “Просвіти” в Коломиї в документах Центрального державного історичного архіву в Львові. Питання історії України. Чернівці : Золоті литаври, 2000. Т. 4. С. 377-382.

${ }^{4}$ Зуляк I. Роль “Просвіти” у поширенні економічних знань у Східній Галичині (кінець XIX - початок ХХ ст.). Україна : культурна спадщина, наиіональна свідомість, державність. Львів, 2010. Вип. 19. C. $151-160$.

${ }^{5}$ Монолатій І. Цісарська Коломия. 1772-1918. Івано-Франківськ : Лілея-НВ, 2010. 312 с.

${ }^{6}$ Середяк А. Діяльність товариства "Просвіта" в 1868-1914 pp. Нарис історії "Просвіти”. Краків ; Париж ; Львів, 1993. С. 18-42.

7 Королько А. Статути "Просвіти" - головний чинник організації діяльності філій і читалень українських культурно-просвітніх товариств в Галичині (остання третина XIX - початок XX ст.). Калуські історичні cmydii. Т. 3 : Збірник наукових статей, документів і матеріалів, присвячений 150-річчю створення товариства "Просвіта". Івано-Франківськ, 2019. С. 29-41; Королько А. Діяльність осередків товариства "Просвіта" на Покутті наприкінці XIX - початку XX ст. (за матеріалами часопису “Діло"). Покуттля колиска украӥнського національного державотворення. Івано-Франківськ, 2018. С. $237-266$.

${ }^{8}$ Центральний державний історичний архів України, м. Львів (далі - ЦДІАЛ України). Ф. 348. Товариство “Просвіта", м. Львів. Оп. 1. Спр. 2941: Списки членів філіалу в м. Коломия. 1880-1916 рр. 68 арк.; Ф. 348. Оп. 1. Спр. 2942: Листування з філіалом в м. Коломия про проведення зборів, нарад, затвердження статутів та інші організаційні питання. 1889-1913 рр. 223 арк.; Ф. 348. Оп. 1. Спр. 2943: Протоколи засідань і загальних зборів членів філіалу в м. Коломия. 1897-1938 pp. 115 арк.; Ф. 348. Оп. 1. Спр. 2944: Звіти про діяльність філіалу в м. Коломия. 1899-1939 рр. 140 арк.; Ф. 348. Оп. 1. Спр. 2959: Звіти, протоколи, листування та інші матеріали про діяльність читальні ім. Т. Шевченка в м. Коломия. 1899-1937 pр. 76 арк.
} 
українського населення краю. Для кристалізації організаційних форм роботи і посилення діяльності головного осередку "Просвіти" у м. Львів потрібно було відкривати нові філії і читальні товариства". А тому перші читальні на власних статутах "Просвіта" почала закладати на початку 1890 -х pp. ${ }^{10}$. Згідно нового статуту, автором якого був О. Колесса, читальні "Просвіти" за допомогою керівного осередку у м. Львів та філій на місцях мали створювати рільничогосподарські і промислово-торгівельні спілки, щадничі і позичкові товариства, шпихліри та крамниці, влаштовувати відкриті лекції, вечорниці, організовувати господарські і промислові виставки, навчати правильному веденню сільськогосподарських робіт, відкривати господарські і промислові школи ${ }^{11}$.

Координуючим центром діяльності низки осередків "Просвіти" на місцях були філії, які знаходились у повітових містах. Їм підпорядковувалася робота читалень товариства, які зосереджувались по селах і містечках краю. 24 січня 1894 р. керівництвом культурно-просвітницького товариства був прийнятий перший устав (статут) для читалень “Просвіти"12.

На початку 1898 р. на загальних зборах “Просвіти” у м. Львові її голова Юліан Романчук заявив, що в організації діяльності осередків товариства на місцях має бути певна децентралізація. Нагляд за культурно-просвітницькою працею читалень має здійснювати не головний осередок "Просвіти" у м. Львів, а відповідні філії товариства на місцях. Тому 3 плином часу філія "Просвіти" повинна знаходитися не тільки в центрі адміністративнополітичного повіту, але й в центрі судового повіту ${ }^{13}$.

В 1908 р. головним осередком “Просвіти” у м. Львів підготовлені збірник правил (регулямін) та інструкція щодо діяльності філій товариства. Керівний осередок філії, передусім його голова, $є$ керманичем читалень "Просвіти" у своїй окрузі. У свою чергу, читальні товариства повинні бути вогнищем праці для просвіщення народних мас. Для організації і регулювання такої роботи мають створюватись спеціальні читальняні комісії. Провідники читальняної роботи по селах краю зобов'язані звертати увагу на такі ділянки праці: загальнопросвітню, економічно-господарську і суспільно-правничу. Представники читальняної комісії філії “Просвіти" зобов'язані щомісячно відвідувати збори читальні та хоча б раз в рік проводити люстрацію (перевірку) читальні. Щонайменше тричі на рік голова філії “Просвіти” повинен скликати збори голів або обраних відпоручників читалень та всіх мужів довір'я на спільну нараду, на яких мають подаватися методичні поради щодо подальшого ведення читальняної роботи. На останньому календарному засіданні заслуховується генеральний звіт про стан діяльності читалень у повіті. Після цього голова філії має відредагувати всі звіти місцевих осередків і загальний звіт про роботу читалень у повіті та надіслати цей матеріал головному осередку “Просвіти” у м. Львів. Окрім цього, голова філії (відпоручник філії) повинен контролювати касове діловодство філії, збір членських внесків, приймати відповідні рішення та надсилати дані до керівного ядра товариства у м. Львів. Визначені як відпоручники філії мужі довір'я зобов'язані опікуватися роботою читалень, здійснювати їх перевірку, виголошувати звіти, долучатися до створення нових осередків товариства ${ }^{14}$.

Осередок “Просвіти” у м. Коломия формувався на підвалинах Руського (Українського) літературно-драматичного товариства, заснованого 30 листопада 1879 р., і місцевої читальні (1878). Руське літературно-драматичне товариство у своєму розвитку ставило такі завдання: представляти театральні аматорські вистави; дбати про розвиток і збагачення руської (української) драматичної літератури шляхом видання творів вітчизняних і іноземних драматургів;

\footnotetext{
${ }^{9}$ Новый статут Товариства “Просвђта”. Батькоิвщчина. 1891. 22 марта (3 цвђтня). Ч. 12. С. 72.

${ }_{10}^{10}$ Сорок лїт дїяльности “Просьвіти”. Дїло. 1908. 8 грудня (25 падолиста). Ч. 276. С. 1.

11 Загальниิ Зборы товар. Просвђта. (Конець). Дгло. 1890. 13 (25) серпня. Ч. 182. С. 2.

12 Першій уставъ для Читалень “Просвьты” ухваленый Головнымъ Выдъломъ товариства "Просвђта" у Львовђ дня 24 н. ст. сьчня 1894 р. Дгло. 1894.19 (31) січня. Ч. 14. С. 1-2.

${ }^{13}$ Промова головы товариства “Просвъты” Юл. Романчука на загальныхъ зборахъ. Дгло. 1898. 22 сьчня (3 лютого). Ч. 17. С. 1.

${ }^{14}$ Регулямін і інструкция для видїлу філії “Просьвіти”. Дїло. 1908. 5 червня (23 мая). Ч. 124. С. 2-3.
} 
сприяти заснуванню Народного дому в м. Коломия. Протягом 1879-1882 pр. товариство поставило 24 театральні вистави ${ }^{15}$.

Філія “Просвіти” у м. Коломия відкрита 27 лютого 1877 р. Першим іiі головою був о. Іван Левицький, його заступником обрано о. Миколу Лепкого, а секретарем - Ісидора Трембіцького. Перше десятиліття осередок товариства, як засвідчує тогочасна українська газетна періодика, не проявляв особливої активності у розвої національно-культурного життя українства краю. У 1880 р. до складу коломийської філії "Просвіти” входило 60 членів, переважно це були вчителі і священики краю. Кожен п'ятий з них був коломиянином: видавець, редактор і журналіст Михайло Білоус (1838-1913), учитель Амброзій Галицький, священики о. Іван Коблянський, о. Антоній Волянський, Йосиф Кульчицький, гімназійний катехит о. Микола Лепкий, Клим Лукашевич, М. Остафійчук, судовий ад'юнкт А. Решетилович, Віктор Слазинський, учитель Ісидор Трембіцький, гімназійний професор Теофіл Грушкевич ${ }^{16}$.

Піднесення діяльності культурно-просвітницького осередку пов'язане 3 обранням у 1889 р. на посади заступника голови філії проф. Т. Грушкевича і секретаря І. Гарасимовича, які регулярно влаштовували культурно-освітні і мистецькі заходи та готували звіти про свою роботу, направляли своїх членів 3 виступами до читалень сіл краю і для заснування нових осередків "Просвіти"17. У звіті філії за 1889 р. зазначалося: "На основі рішення нашого Виділу (керівництва осередку. $-A$. K.) $з$ дня 26 липня с. p. і рішення загальних зборів Товариства в Станиславові 3 дня 29 серпня зайнялася наша філія долею сільських читалень" ${ }^{\text {. }}$. Члени філії відвідували читальні з лекціями, допомагали в створенні нових читалень, розповсюджували українські книжки ${ }^{19}$. Філія “Просвіти” у м. Коломия 25 березня 1889 р. однією $з$ перших у Східній Галичині організувала поминальне богослужіння 3 нагоди річниці смерті громадськополітичного діяча, члена-засновника "Просвіти", Товариства ім. Шевченка, Народного дому, Народної ради, “Руського товариства педагогічного” Степана Качали (1815-1888)

Знаковою подією національно-культурного пробудження українців краю стало проведення загальних зборів керівного осередку “Просвіти” в м. Коломиї 28 серпня 1890 р., яку організувала місцева філія культурно-просвітницького товариства ${ }^{21}$. Це були тільки другі збори з 1868 р., проведені не в м. Львів. Перший подібний захід організований у м. Станиславові в 1889 р. На загальних зборах “Просвіти” в головному місті Покуття мали розглядати два основні питання: будівництво власного будинку товариства в м. Львів та розгляд проекту Олександра Колесси про зміну статуту щодо розширення діяльності читалень "Просвіти" 22. Після цього повинні були відбутися “селянські вечорниці", влаштовані коломийською філією "Просвіти”, де хорові колективи і окремі виконавці з м. Коломия і м. Снятин та сіл Воскресінці, Балинці (нині село входить до складу Снятинського району Івано-Франківської обл.) Коломийського повіту, Іллінці Снятинського повіту, Космач Печеніжинського повіту (нині село у складі Косівського району Івано-Франківської обл.), Тишківці Городенківського повіту, Ворохти Надвір-

\footnotetext{
15 Товариства для поิддержки товариского и народного житя. I. Перше руске літературно-драматичне товариство въ Коломыђ. Илюстрованыци калєндарь товариства “Просвтта” на роิкъ звычайныцй 1886. Львовъ, 1885. С. 84-85.

${ }_{16}^{16}$ ЦДІАЛ України. Ф. 348. Оп. 1. Спр. 2941. Арк. 1-2.

17 Філії “Просьвіти". 7. Філїя в Коломиї ... Справозданє з дїяльности Товариства "Просьвіта" за час від 1. сїчня 1898 до 31. грудня 1899. Львів : 3 друкарнї Наукового Товариства імени Шевченка, 1900. С. 13-14; ЦДІАЛ України. Ф. 348. Оп. 1. Спр. 2942. Арк. 7-8.

${ }^{18}$ Там само. Арк. 7 зв.

${ }^{19}$ Гарат Р. М. Філія “Просвіти” в Коломиї в документах Центрального державного історичного архіву в Львові... С. 377.

${ }^{20}$ ЦДІАЛ України. Ф. 348. Оп. 1. Спр. 2942. Арк. 1-2.

${ }^{21}$ Там само. Арк. 12 зв. ; До Русино̂в зъ повътоิвъ: Коломыйского, Снятиньского, Косоิвского, Городеньского и сусьдныхъ. Дголо. 1890. 3 (15) серпня. Ч. 175. С. 1; Савчук М. Просвітяни Галичини з’іхалися до Коломиї. Слово Просвіти. 2018. 6 грудня. URL: http://slovoprosvity.org/2018/12/06/prosvityany-halychynyzjihalysya-do-kolomyji.

22 Загальнй Зборы товар. Просвъта. Дгло. 1890. 11 (23) серпня. Ч. 181. С. 1.
} 
нянського повіту мали виконати музичні твори М. Лисенка, М. Вербицького, А. Вахнянина, С. Воробкевича, В. Матюка та виголосити поезії Т. Шевченка ${ }^{23}$.

На збори товариства прибуло близько 1500 учасників. Серед поважних гостей були присутніми депутати австрійського парламенту і Галицького крайового сейму Т. Окуневський, К. Гаморак. Й. Гурик, Д. Савчак. Розпочалося урочисте дійство 28 серпня 1890 р. о 8 год з богослужіння у місцевій церкві, яку відправив о. І. Коблянський. Він також відкрив загальні збори "Просвіти" 24 . Після цього сформовано секретаріат засідань, до складу якого ввійшли нотаріус В. Левицький та депутат Т. Окуневський. Із привітальним словом виступив голова "Просвіти" Омелян Огоновський. Однак після цього місцева влада на годину перервала роботу загальних зборів, мотивуючи тим, що в канцелярію коломийського староства не надійшло відповідне повідомлення про організацію українцями проведення даного заходу (до речі, 21 серпня, за тиждень до початку проведення загальних зборів, секретар коломийської філії “Просвіти" І. Гарасимович у листі до керівного осередку товариства у Львові бідкався, що підрозділ військової частини, за погодженням бурмистра, “запакував" 24 вози на місці, де мав відбутися просвітянський захід ${ }^{25}$ ). Тому депутація просвітянських зборів (О. Огоновський, Д. Савчак, Т. Окуневський, В. Лаврівський, І. Гарасимович) звернулася зі скаргою до комісара коломийського староства Крушинського, який дозволив проводити цей захід (з приводу цього інциденту у стінах Галицького крайового сейму 18 жовтня 1890 р. розглядалася інтерпеляція (звернення) Т. Окуневського 26$)^{27}$.

Після відновлення роботи головою зборів обрано Д. Савчака, а його заступником Й. Гурика. Вибраний новий склад головного осередку "Просвіти" у м. Львів на чолі з О. Огоновським. За заслуги в розвитку українського національного просвітництва в лави товариства прийняті нові почесні члени - це відомі громадські діячі з Наддніпрянщини і Галичини В. Антонович, О. Кониський, І. Нечуй-Левицький, П. Житецький, В. Федорович, С. Дубравський, а також чеський науковець Ф. Ржегорж. У часописі “Діло” і “Батькоิвщина” поданий детальний звіт про проведення даного заходу. На ньому виступили В. Лаврівський, В. Шухевич, Т. Окуневський, О. Барвінський, О. Колесса, К. Трильовський, Я. Невестюк та інші. Особливе зацікавлення серед учасників зборів мав виступ Олександра Колесси про новий проект статуту "Просвіти" щодо створення на місцях читалень товариства. Після цього відбулися святкові вечорниці, де виступили хорові колективи краю. Завершився святковий захід співом національного гімну "Ще не вмерла Україна" 28 . Загальні витрати на проведення урочистостей становили 81,583 sp. $^{29}$.

Коломийська філія “Просвіти” на початку 1890-х рр. підтримувала розвиток українського шкільництва краю. Так, після відкриття української гімназії в м. Коломиї в 1892 р. культурно-просвітницький осередок пожертвував місцевому відділенню товариства "Шкільна поміч” матеріальну допомогу в сумі 25 зр. для утримання учнів першого класу новоствореного навчального закладу: "Поміч для учеників тої кляси потрібна, бо родичі мусять купувати другий раз книжки, а біднійшим се за трудно"з3.

Протягом 1890-х рр. мистецькі заходи філія "Просвіти” у Коломиї проводила спільно 3 іншими українськими товариствами (“Коломийський Боян”, Руське літературно-драматичне

\footnotetext{
23 Загальни̂ Зборы товар. Просвظта. (Конець). Дголо. 1890. 13 (25) серпня. Ч. 182. С. 1-2.

${ }^{24}$ ЦДІАЛ України. Ф. 348. Оп. 1. Спр. 2942. Арк. 13.

${ }^{25}$ Там само. Арк. 16, 16 зв.

${ }^{26}$ Справы соймовиि. Батькоิвщина. 1890. 24 жовтня (5 листопада). Ч. 43, 44. С. 542-543.

${ }^{27}$ Выдъль товариства “Просвъты” заразъ по Загальныхъ Зборахъ товариства въ Коломыи зажадавъ оिдь уряду почтового розсльдженя... Дголо. 1890. 28 серпня (9 вересня). Ч. 194. С. 1.

Загальни̂ Зборы товариства "Просвьты” въ Коломыи. Дгло. 1890. 18 (30) серпня. Ч. 186. С. 1-3; 20 серпня (1 вересня). Ч. 187. С. 1-2; Загальни̂ Зборы товариства "Просвьты” въ Коломыи. Батькоิвщина. 1890. 24 серпня (5 вересня). Ч. 34 и 35. С. 435-441; 7 (19) вересня. Ч. 37. С. 466-469; 21 вересня (3 жовтня). Ч. 38 и 39. С. 482-484.

${ }^{29}$ ЦДІАЛ України. Ф. 348. Оп. 1. Спр. 2942. Арк. 19.

${ }^{30}$ Видїл товариства "Просьвіти" на послїднім своїм засїданю ухвалив пожертвувати на руки "Шкільної Помочи” в Коломиї ... Батьківщина. 1892. 4 (16) вересня. Ч. 36. С. 180. Рубр.: Всячина і новинки.
} 
товариство та ін.), які функціонували в місті. Тогочасні газетні дописи засвідчують, що вони були присвячені, передусім, вшануванню пам'яті Т. Шевченка і М. Шашкевича. Зокрема, вечір вшанування пам’яті Кобзаря був проведений у Коломиї 17 березня 1898 р. Декламувалися поезії Т. Шевченка, на його слова лунали пісні ${ }^{31}$.

Все ж, зі звіту представника головного осередку “Просвіти" у м. Львів про діяльність філії товариства протягом 1 січня 1892 р. - 31 грудня 1893 р. вказувалося, що коломийський осередок проявив слабшу діяльність 3 причини “некорисних відносин між нашою інтелігенцією в Коломиі”. В наступному загальному звіті керівного осередку “Просвіти” за час від 1 січня 1894 р. до 31 грудня 1895 р. вказувалося, що "новий філіяльний виділ не розвинув ширшої діяльності у своєму повіті”. Діловодство провадив виключно заступник голови філії професор місцевої української гімназії о. Микола Лепкий ${ }^{32}$.

20 червня 1894 р. коломийська філія "Просвіти” провела загальні збори, на яких обрано новий керівний склад осередку товариства: голова - директор місцевої школи Григорій Кульчицький, заступник голови і касир - о. Микола Лепкий, секретар - радник суду і адвокат Павло Ільницький, контролер і завідувач книжного складу - о. Клим Кульчицький, заступники гімназійний професор Михайло Пачовський, катехит о. Олександр Русин і господар з с. Корнич Петро Ганущак, а також радник суду Тит Заячківський, парох у м. Печеніжин о. Іван Шмериковський, гімназійний професор Юліан Кобилянський ${ }^{33}$. Також було заслухано дві доповіді про розвиток просвітництва у краї та про користь ведення пасічництва ${ }^{34}$. Новообраний голова Григорій Кульчицький в листі від 8 квітня 1894 р. до керівництва “Просвіти” у м. Львів писав: "Вибраний Загальним Збором дня 20 червня 1894 р. виділ занявся передовсім упорядкуванням справ філії і оживленням іï, так як від п’яти літ філія не проявляла ніякого життя. Діяльність філії ледве $з$ часом буде могти належно розвинутись і обняти справді ціле Покуте - а то $з$ тої причини що через довголітню безчинність (бездіяльність. $-A$. $K$.) вплив і значення єї в окресности зовсім зникли - і треба направляти і поборювати багато злого"35.

8 грудня 1894 р. філія товариства у м. Коломия, незважаючи на перешкоди місцевих москвофілів, організувала поминальне богослужіння 3 нагоди вшанування пам'яті відомого українського вченого-філолога, громадського діяча, голови “Просвіти" (1877-1894) Омеляна Огоновського (1833-1894). На заході виступили не тільки члени місцевого осередку "Просвіти", але й представники товариства сусідніх покутських повітів. Зокрема, “кульмінаційною точкою богослужіння" стала патріотична проповідь одного 3 керівників "Просвіти" Городенківського повіту, священика з с. Торговиця пільна (нині с. Торговиця Городенківського району Івано-Франківської обл.) Алоїзія Олесницького. Після літургії члени "Просвіти", викладачі місцевої гімназії і близько ста селян зібралися у приміщенні товариства "Родина". Під час дружньої бесіди обговорювалися питання про потребу заснування крамниць і громадських шпихлірів (зерносховищ) та активного ведення культурно-просвітницької роботи ${ }^{36}$. У вересні 1896 р. керівництво читальні "Просвіти" в с. Іспас Коломийського повіту висловило щиру подяку філії товариства в м. Коломиї за подаровані книги ${ }^{37}$.

19 листопада 1897 р. на загальних зборах філії “Просвіти” обране нове керівництво: голова - судовий радник Тит Заячківський, заступник голови - гімназійний професор Остап Макарушка, секретар - Іван Гомик, касир - о. Олександр Русин, контролер - о. Іван

\footnotetext{
31 Зъ Коломыъ пишуть намъ... Дгъло. 1898.7 (19) марта. Ч. 53. С. 2. Рубр.: Новинки.

32 Справозданье зъ дъятельности Товариства "Просвђта" за часъ воिдь 1 сьчня 1892 до 31 грудня 1893 року. Дглол. 1894. 15 (27) сьчня. Ч. 11. С. 1; Справоздане зъ дъяльности товариства "Просвъта" за часъ воิдъ 1 съчня 1894 р. до 31 грудня 1895 р. Дгъло. 1896.5 (17) съчня. Ч. 4. С. 2.

${ }^{33}$ ЦДІАЛ України. Ф. 348. Оп. 1. Спр. 2942. Арк. 25.

34 Загальниि зборы коломыйскои філіи “Просвьты”... Дюло. 1894. 30 мая (11 червня). Ч. 120. С. 3. Рубр.: Новинки.

${ }^{35}$ ЦДІАЛ України. Ф. 348. Оп. 1. Спр. 2942. Арк. 29, 29 зв.

${ }_{36}^{36}$ Азъ Буки. Зъ Коломыъ пишуть намъ... Дглол. 1894. 2 (14) грудня. Ч. 270. С. 3-4. Рубр.: Новинки.

37 Воิдъ выдълу. Выдълъ читальнъ въ Испасъ побоิчь Коломыи складає... Дгъло. 1896. 30 серпня (11 вересня). Ч. 195. С. 3. Рубр.: Новинки.
} 
Шмериковський, “виділові” - о. Тит Войнаровський і селянин Василь Клапчук ${ }^{38}$. Самовіддана праця членів філії "Просвіти” дала свої результати. За один рік були відкриті читальні у селах Острівець (нині село Городенківського району Івано-Франківської обл.), Мишин, Семаківці Коломийського повіту та містечко Кути Косівського повіту, керівництво осередку посилало делегатів на збори у с. Яблунів (нині село Косівського району Івано-Франківської обл.), с. Балинці, м. Печеніжин. Члени філії вбачали причини недостатнього розвитку “Просвіти” в тому, що велика частина священиків, учителів і місцевої інтелігенції трималися осторонь просвітницької роботи. Інтелігенція робила багато корисних справ тільки у політичній сфері діяльності, а на економічно-просвітницьку роботу “треба побудити священство і учительство взагалі”,39. Для залучення більшої кількості селян до "Просвіти” і для того, щоб вони мали не тільки моральну, але й матеріальну зацікавленість, було вирішено: “старатися о достарчення доброго і дешевого насіння для селян; машини господарські будуть могли доставати члени за готівку з опустом (знижкою. - А. К.) 20\%; товариство асекураційне (страхове. - А. К.) “Дністер” буде давати для членів $10 \%$ опусту"

Початок нової хвилі піднесення осередку товариства припадає на 1899 р. завдяки діяльності новообраного керівного осередку “Просвіти” (голова Василь Глинський, заступник голови Леонтій Кузьма, секретар Іван Гомик) ${ }^{41}$. На філію товариства було поставлене непросте завдання: “... не лишень розбудити тяженьке, напівдрімуче тїло тутешної народної суспільности, але по змозі влити в него тої привотворної сили, щоб, розбудившись, жило, кріпшало, дїлало, розвивалось" ${ }^{\text {,2 }}$. Його члени задекларували три напрямки культурно-просвітницької роботи: створення нових читалень "Просвіти”; сприяння у відкритті крамниць і позичкових кас; ведення просвітницько-економічної діяльності серед ширших верств населення ${ }^{43}$.

Уже в перший рік за підтримки керівництва філії відкрито дві нові читальні “Просвіти" в с. Шепарівці і с. Турка (нині с. Годи-Добровідка Коломийського району Івано-Франківської обл.), три - підготовлені для відкриття (загалом, на початок 1900 р. під орудою філії "Просвіти" діяла 21 читальня, в яких налічувалося понад 500 членів $\left.{ }^{44}\right)^{45} .6$ червня 1899 р. філія "Просвіти" спільно з іншими українськими культурно-просвітницькими товариствами міста організувала концерт 3 нагоди вшанування 38-х роковин смерті Тараса Шевченка. Зібрані кошти з проведеного дійства мали бути передані для потреб знедолених школярів української гімназії в м. Коломиі ${ }^{46}$.

Реалізуючи третій напрям роботи, 8 грудня 1899 р. філія влаштувала просвітно-економічне віче в м. Коломия ${ }^{47}$, в якому взяло участь понад 500 людей (за іншими даними 400 людей $\left.^{48}\right)$. На думку іï організаторів, це була “перша проба в ширеню просьвіти і почутя

\footnotetext{
${ }^{38}$ ЦДІАЛ України. Ф. 348. Оп. 1. Спр. 2943. Арк. 2 зв.

${ }^{39}$ Там само. Арк. 1-2 зв.

${ }^{40}$ Там само. Арк. 2.

${ }^{41}$ Там само. Спр. 2941. Арк. 12.

${ }^{42}$ Там само. Спр. 2944. Арк. 5.

${ }^{43}$ Там само. Арк. 43.

${ }^{44}$ Там само. Арк. 43 зв.

${ }^{45}$ Філііі “Просьвіти". 7. Філїя в Коломиї... Справоздане з дїяльности Товариства "Просьвіта" за час від 1. сїчня 1898 до 31. грудня 1899. Львів : 3 друкарнї Наукового Товариства імени Шевченка, 1900. С. 13-14; Въ коломыйскоิмъ повътъ. Свобода. Письмо політичне, просвътне и господарске для народу. 1899. 18 (6) мая. Ч. 19. С. 150. Рубр.: Рухъ політичный, просвђтный и економічный руского народу ; В коломийскім повітї: Загальні збори філії товариства "Просьвіта" в Коломиї відбули ся... Свобода. Письмо політичне, просвътне и господарске для народу. 1899. 25 червня (7 липня). Ч. 26. С. 206. Рубр.: Рухъ політичный, просвьтный и економічный руского народу. ЦДІАЛ Украӥни. Ф. 348. Оп. 1. Спр. 2942. Арк. 67, 70.

46 Зъ Коломыи пишуть нам... Свобода. Письмо політичне, просвътне и господарске для народу. 1899. 21 мая (1 червня). Ч. 21. С. 166. Рубр.: Новины.

${ }^{47}$ Въче въ Коломыи. Свобода. Письмо політичне, просвътне и господарске для народу. 1899. 11 (23) падолиста. Ч. 46. С. 367. Рубр.: Новины; ЦДІАЛ Украӥни. Ф. 348. Оп. 1. Спр. 2942. Арк. 70 зв.

48 Письмо зъ Коломыъ. [Просвътно-економічне въче коломыйскои філіи “Просвъты”]. Дголо. 1899. 22 грудня (3 сьчня 1900). Ч. 286. С. 2.
} 
солїдарности між ширшими масами нашого народу через віча" ${ }^{\text {"49 }}$. Після церковного богослужіння в головному українському храмі міста учасники віча зібралися в залі магістрату, де обрали голову засідання о. Т. Войнаровського. На зібранні виступили: М. Коцюба з Станиславова про організацію ремісничих і рільничих навчальних закладів, згадавши про діяльність шкіл гончарного і деревного промислу в м. Коломия та школи рільництва в м. Городенці, наголосивши про вступ селянських дітей на торгівельні курси, які організовує українське кооперативне товариство “Народна торгівля”; доктор медицини 3. Левицький про охорону здоров'я краян; селяни І. Драган з с. Балинці і В. Дутчак з с. Коршів Коломийського повіту про заснування і діяльність українських крамниць; проф. О. Колодницький про потребу заснування позичкових кас; проф. П. Мостович про забезпечення сільських громад краю худобою. На завершення культурно-просвітницького заходу його учасники заспівали гімн “Ще не вмерла Україна",50.

Оживленням роботи читалень "Просвіти" на Коломийщині у цей час займався передусім заступник місцевої філії ( 1900 р. ії голова) Леонтій Кузьма. Лише в 1899 р. він здійснив 14 поїздок по селах краю, намагаючись піднести рівень роботи осередків товариства ${ }^{51}$. Українська преса краю початку XX ст. високо оцінювала його діяльність. Л. Кузьма організовував просвітницькі віча у м. Коломиї та навколишніх селах з добірно підготовленими програмами $\mathrm{i}$ виголошеними рефератами: "Вже інтелїгенция не цураєсь вихилити голову по за брами міста i їхати на село, щоб нести лучі справдїшного сьвітла до менших братів, під сїльску, курну хату" ${ }^{\prime 2}$.

Щотижня в 1900 р. філія “Просвіти” запровадила читання проф. І. Раковським науковопізнавальних лекцій на природничі теми: "Хвороби заразливі і їх причини” (11 березня), "Море і його чудеса" (18 березня), "Вороги людського здоров'я” (25 березня), “Будова людського тіла” (1 квітня). Даний сегмент культурно-просвітницької роботи осередку товариства був спрямований в адрес українського селянства і був своєрідною відповіддю проти подібної праці польських культурно-освітніх кіл (діяльності т. зв. людового університету): вони будуть “кращою поживою”, ніж “неясні ремінісценції зі "szkoły ludowej” про "zaczarowanych królewnach i śpiących królach"”, 53 .

12 і 22 березня 1900 р. філія "Просвіти" в м. Коломия спільно з музично-хоровим товариством "Коломийський Боян” організували величне свято 3 нагоди 39-х роковин смерті Тараса Шевченка ${ }^{54}$. Філія товариства вимагала від кожної читальні Коломийського повіту підготувати “відчит" (реферат) про життя і творчість Кобзаря. Для цього в кожен населений пункт краю були розіслані відповідні відозви ${ }^{55}$.

1 квітня 1901 р. у Коломиї відбулися загальні збори філії товариства та святковий вечір 3 нагоди 40-х роковин смерті Т. Шевченка ${ }^{56}$. У загальному звіті про діяльність керівного осередку товариства вказувалося, що, попри перешкоди москвофілів і окремих радикалів, у

\footnotetext{
${ }^{49}$ ЦДІАЛ України. Ф. 348. Оп. 1. Спр. 2944. Арк. 1.

50 Письмо зъ Коломыђ. [Просвътно-економічне въче коломыйскои філіи “Просвђты”]. Дголо. 1899. 22 грудня (3 сьчня 1900). Ч. 286. С. 2; Філії “Просьвіти”. 7. Філїя в Коломиї... Справоздане з дїяльности Товариства "Просьвіта" за час від 1. сїчня 1898 до 31. грудня 1899. Львів : 3 друкарнї Наукового Товариства імени Шевченка, 1900. С. 13-14; Справозданє Народного Комітету. (Дальше). Дгло. 1900. 28 червня (11 липня). Ч. 144. С. 2; ЦДІАЛ України. Ф. 348. Оп. 1. Спр. 2944. Арк. 1-4.

${ }^{51}$ ЦДІАЛ України. Ф. 348. Оп. 1. Спр. 2944. Арк. 5 зв.

${ }^{52}$ Кригулець М. Огляд народної роботи в Коломийщинї (Допись). Дгъло. 1902. 15 (28) марта. Ч. 61. С. 2.

53 Олегъ Сатиръ. Зъ Коломыђ [Популярно-науковиิ выклады коломыйскои філіи “Просвьты”]. Дголо. 1900. 3 (16) марта. Ч. 51. С. 2. Рубр.: Письма зъ краю; Справозданє Народного Комітету. (Дальше). Дголо. 1900. 28 червня (11 липня). Ч. 144. С. 2.

${ }^{54}$ А. Л. Зъ Коломыъ пишуть нам... Дголо. 1900. 3 (16) марта. Ч. 51. С. 2-3. Рубр.: Обходы въ память Т. Шевченка.

${ }_{55}$ Філїя "Просьвіти" в Коломиї, устроює дня 22 н. ст. марта с. р. великий сьвяточний обхід в честь Тараса Шевченка... Свобода. Політичне, просьвітне $i$ господарске письмо для народу. 1900. 24 лютого (8 марта). Ч. 8. С. 4. Рубр.: Новини.

${ }^{56}$ Зъ Коломыъ. Выдълъ коломыйскои філіи “Просвьты” оповъщує... Дгъло. 1901. 3 (16) марта. Ч. 50 . С. 3. Рубр.: Новинки.
} 
1900 р. вдалося відкрити три нові читальні на Коломийщині. Обраний новий керівний склад філії товариства, до якого ввійшли Леонтій Кузьма, Олекса Печерський, о. Н. Гриньовський, Іван Гомик, Олександр Кульчицький, Іван Раковський, Василь Дутчак 3 с. Коршів, Олекса Верстюк $з$ с. Бучачки Коломийського повіту (нині село Снятинського району Івано-Франківської обл.), Лев Посацький і Омелян Колодницький ${ }^{57}$. Кожен з учасників зборів отримав видану коштом філії товариства книжечку, в якій містився календар, заклик для вступу в лави "Просвіти”. Після цього о 7 год. вечора у приміщенні каси ощадності відбулися шевченківські вечорниці. Програма заходу складалася з таких частин: вступне слово проф. О. Колодницького та завершальне О. Кульчицького; промова селянина з с. Балинці І. Каралаша про життя і діяльність Т. Шевченка; виступи музично-хорового товариства "Коломийський Боян” та чоловічого хору читальні "Просвіта" с. Балинці під орудою В. Барнича; декламування поезій Т. Шевченка, І. Франка та С. Руданського просвітянами Ю. Мочернюком з с. Ковалівки (“Катерина” Т. Шевченка) і Ф. Боднаренком з м. Печеніжин (“На святоюрській горі” І. Франка, сміховинки С. Руданського). Леонтій Кузьма подбав про прикрашення сцени вісьмома художніми кліше з життя Кобзаря: хата, де народився письменник; його портрет у віці 28 років; Т. Шевченко - у солдатському засланні, в тюрмі, сидить на кріслі, в шапці; портрет Кобзаря та хрест, які висять на його могилі в м. Каневі. Завершувалися урочисті заходи у приміщенні Руського (Українського) народного дому (суч. вул. Театральна, 25), де “при співах і бесідах забавляли ся зібрані до пізна в ночи". Кошти з проведеного вечора мали піти на спорудження пам'ятника Т. Шевченку в Коломиї ${ }^{58}$.

Щотижня, з 28 квітня до кінця червня 1901 р., у приміщенні Руського (Українського) народного дому члени філії товариства проводили популярно-наукові “відчити” на історичну, літературну та гігієнічну теми ${ }^{59} .30$ травня 1901 р. місцева "Просвіта", спільно з іншими українськими культурно-мистецькими товариствами, влаштувала концерт на честь Кобзаря. Зібрані кошти 3 проведеного дійства мали піти на розвиток товариств “Шкільна поміч" та "Народний дім" в Коломиї.

Своєрідним проміжним підсумком праці осередку товариства стало організація в м. Коломия 1 листопада 1901 р. просвітно-господарського віча 3 нагоди 25-річчя діяльності філії "Просвіти"61. Напередодні його проведення у спеціально підготовленій відозві "Браття Земляки покутської Руси-України" вказувалося: "Не нам самих себе судити! Нехай нас судить істория та безсторонна критика своїх і чужих. Наша філїя Просьвіти вижидає спокійно того суду, бо через цїлих 25 лїт она по змозї, але совісно сповняла свою цїль і свою задачу; а що плоди сего нашого спільного труду може не такі сьвітлі, як-би ми собі сего бажали, що овочі сеї нашої чвертьстолїтної діяльности може не дорівнують тому, що собі здобули за той час сусїдні народи, то винні тому тяжкі обставини, серед яких проживав в сїм часї весь наш руско-український народ"62. На вічі планувалося представити “велику бібліотеку”, в якій селяни отримали б книги для своїх сільських читалень "Просвіти".

Святкове дійство розпочалося з богослужіння в головному греко-католицькому храмі міста. Після цього урочисті збори продовжилися в залі міського магістрату, які відкрив керівник філії "Просвіти” Л. Кузьма. Головою президії обрано одного з перших очільників товариства о. М. Лепкого (за іншими даними першого голову коломийської “Просвіти” о. І. Левицького ${ }^{63}$ ). Директор Борковський виголосив доповідь про важливість навчання і просвіти для

\footnotetext{
${ }^{57}$ ЦДІАЛ України. Ф. 348. Оп. 1. Спр. 2944. Арк. 9.

58 Коломиї. Свобода. Політичне, просьвітне і господарске письмо для народу. 1901. 9 мая (26 цьвітня). Ч. 17. С. 2-3. Рубр.: Дописи.

${ }^{59}$ ЦДІАЛ України. Ф. 348. Оп. 1. Спр. 2944. Арк. 9.

60 Зъ Коломыъ. Програма концерту Шевченка устроюваного заходомъ всьхъ рускихъ товариствъ дня 30 мая... Дгло. 1901. 15 (28) мая. Ч. 107. С. 3. Рубр.: Новинки.

${ }^{61}$ ЦДІАЛ України. Ф. 348. Оп. 1. Спр. 2942. Арк. 106; ЦДІАЛ Украӥни. Ф. 348. Оп. 1. Спр. 2944. Арк. 9 зв.

${ }^{62}$ Братя Земляки покутскоі Руси-України! Дголо. 1901.8 (21) жовтня. Ч. 225, 226. С. 3.

${ }^{63}$ Народне сьвято Покутскоі Руси. Свобода. Політичне, просьвітне $і$ господарске письмо для народу. 1901. 7 падолиста (25 жовтня). Ч. 43. С. 2.
} 
українського народу та про значення в цій ділянці роботи "Просвіти". Проф. І. Раковський виступив 3 повідомленням про витоки становлення та історичний розвиток коломийської філії "Просвіти". о. А. Олесницький з с. Торговиці пільної Городенківського повіту промовив про важливість відкриття в краї різноманітних економічних спілок і товариств. Урочисті збори закрив голова філії Л. Кузьма, після чого всі присутні заспівали гімн "Ще не вмерла Україна". Після обіду в просторій залі щадничої каси відбувся урочистий концерт, на якому заспівали чоловічий хор “Коломийського Бояна" та змішаний хор с. Балинці, декламували поезії діти 3 с. Пилипи та м. Печеніжин, виступили зі вступною та прикінцевою промовами проф. О. Макарушка і проф. Масляк. Невідомий автор розлогого допису в газеті “Свобода" підсумував проведення цього святкового дійства так: “Цїлий обхід випав величаво і дає надію, що рух народний на Покутю піде тепер значно горою... котрого спомин загрівати буде наших борцїв на Покутю до дальшої витрівалої боротьби за нашу правду і волю!...”64.

19 травня 1902 р. філія товариства "Просвіта" під час Зелених свят влаштувала просвітно-економічне віче, вечір пам'яті Т. Шевченка ${ }^{65}$ та аматорську виставу "Наталка Полтавка" I. Котляревського за участю членів товариства с. Балинці Коломийського повіту. Керівним осередком коломийської філії підготовлено відозву про вшанування пам'яті Т. Шевченка. Подібний вечір пам'яті Кобзаря філія коломийської "Просвіти" організувала наступного року 25 березня у приміщенні Руського (Українського) народного дому (за іншими даними - міського магістрату $\left.{ }^{66}\right)^{67}$. Тоді ж скликані загальні збори товариства за участю понад 200 членів, переважно селян. Обрано новий керівний склад філії “Просвіти”: головою став Омелян Колодницький, його заступником - Лесь Кульчицький. Цікаво, що О. Колодницький брав участь у відновленні читальні товариства сусіднього Косівського повіту - в м. Кути. Однак вже наприкінці 1903 р. він переїхав до польського міста Дембіца (“перенесений на мазури до Дембіци”, ${ }^{\prime 8}$ ), тому деякий час обов'язки голови філії “Просвіта” виконував О. Кульчицький ${ }^{69}$.

Подібний шевченківський вечір відбувся 25 березня 1904 р. після проведених загальних зборів філії "Просвіти” у великому залі Руського (Українського) народного дому, на якому були присутні 350 жителів краю. Про життя і діяльність Генія українського народу виголосив реферат проф. Іван Раковський, з музичними творами виступили хорові колективи села Балинці під орудою В. Барнича і містечка Печеніжин під керівництвом Недільського, поезії Т. Шевченка декламували Ганна Ткачук з с. Кийданч та Боднаренко 3 м. Печеніжин ${ }^{70}$.

Станом на кінець 1903 р., на Коломийщині функціонували 28 читалень “Просвіти”, 3 них за останні два роки відкрито сім осередків ${ }^{71}$.

Регулярне вшанування творчості Т. Шевченка та І. Котляревського коломийськими просвітянами на початку ХX ст. набуло своєрідних форм і пов'язане зі співпрацею 3 наддніпрянськими культурно-просвітницькими діячами. Так, восени 1903 р. полтавчани подарували Руському (Українському) народному дому і філії товариства "Просвіта" у м. Коломия 19 образків до скіоптікону (проекційний пристрій, де подавалися різноманітні зображення форми "laterna magica"), присвячені життю і творчості Івана Котляревського та побуту наддніп-

\footnotetext{
${ }^{64}$ Народне сьвято Покутскоі Руси. Свобода. Політичне, просьвітне і господарске письмо для народу. 1901. 7 падолиста (25 жовтня). Ч. 43. С. 2; Коломыйске свято. Дгло. 1901. 20 жовтня (2 падолиста). Ч. 287. С. 2-3. Рубр.: Новинки.

65 Філїя “Просьвіти” в Коломиї. Дїло. 1902. 11 (24) мая. Ч. 105. С. 2. Рубр.: Рухъ в рускихъ товариствахъ.

${ }^{66}$ ЦДІАЛ України. Ф. 348. ОП. 1. Спр. 2944. Арк. 12.

${ }^{67}$ Видїл коломийскої філії “Просьвіти” повідомляє... Дїло. 1903. 5 (18) марта. Ч. 52. С. 2. Рубр.: Новинки; ЦДІАЛ України. Ф. 348. Оп. 1. Спр. 2942. Арк. 120, 120 зв.; ЦДІАЛ України. Ф. 348. Оп. 1. Спр. 2944. Арк. 11-12.

${ }^{68}$ ЦДІАЛ України. Ф. 348. ОП. 1. Спр. 2943. Арк. 14.

${ }^{69}$ Там само. Спр. 2942. Арк. 133.

70 Там само. Спр. 2943. Арк. 16.

71 Філії “Просьвіти”. 10. Філїя “Просьвіти” в Коломиї. Звіт з дїяльности Товариства “Просьвіта” за час від 1. сїчня 1902 до 31. грудня 1903. Львів : 3 друкарнї Наукового Товариства імени Шевченка, 1903. С. 16-17; Товариство "Просьвіта" в роках 1902 і 1903. ІІ. Філії “Просьвіти". Дїло. 1904. 12 (25) мая. Ч. 105. C. 1-2.
} 
рянських українців (“Пам'ятник І. Котляревського на могилі в місті Полтаві”, “Сцена в селянській хаті (хазяй і хазяйка)”, “Забава з танцями на Україні”, “Хазяйка б’є мужа”, “Дівчина і вислужений салдат - за деревом хазяїн підслухує”, “Салдат в селянській хаті”, “Перестрашений козак з мітлою в руках", "Плачучі селяни перед дівчиною" та ін.) $)^{72}$.

Однак саме в цей час філія коломийської “Просвіти”, попри ініціативність окремих діячів у розбудові товариства, за спостереженнями окремих громадських активістів, займала слабке становище через засилля діяльності в місті українських радикальних, москвофільських та польських культурно-просвітницьких організацій: “... справа “Просьвіти” щойно в починї, бо і тут нема нїякої програми нї органїзациї, ${ }^{\prime 3}$.

Безумовно, українські радикали, завдячуючи енергійній праці Кирила Трильовського та його однодумців, наприкінці XIX - на початку XX ст. займали перші позиції в громадсько-політичному житті краю, сформувавши серйозну мережу осередків економічно-просвітнього "Коломийського товариства Народних Спілок" і пожежно-гімнастичного товариства “Січ”. До того ж в культурно-просвітній роботі "Коломийське товариство Народних Спілок" мала замінити діяльність осередків "Просвіти", які в кінці XIX ст. в переважній більшості не мали популярності серед українських селян Покуття і Галицької Гуцульщини. Громадський діяч, один 3 керівників "Просвіти”, О. Колесса вбачав такі недоліки діяльності читалень "Просвіти”: по-перше, на відміну від польських національно-культурних товариств (“Kółka rolnicze”), українські читальні не займалися наданням соціально-економічної допомоги своїм членам, не створювали позичкові і щадничі каси, промислові і торгівельні спілки, шпихліри, крамниці тощо; по-друге, місцеві осередки "Просвіти” діяли відокремлено одна від одної, не мали впливу на організацію роботи філії товариства; по-третє, не була налагоджена справа звітності товариств ${ }^{74}$. На думку українських радикалів Коломийщини, діяльність читалень "Просвіти" і товариства ім. М. Качковського не підлягали будь-якій критиці. Їх праця підпорядковувалася партійно-політичній заангажованості керівників - народовців і русофілів ${ }^{75}$. На початку XX ст. у населених пунктах краю діяло більше 90 осередків “Коломийського товариства Народних Спілок”, переважно у Коломийському, Снятинському, Косівському і Надвірнянському повітах ${ }^{76}$.

"Батько" українського січового руху та "вічний кандидат" до австрійського парламенту Кирило Трильовський неодноразово намагався втрутитися у роботу філії “Просвіти” у м. Коломия, намагаючись змінити ідеологеми культурно-просвітницької праці товариства. Так, 1 квітня 1901 р. на загальних зборах філії “батько” українського січового руху “став анонсувати свої “Спілки” і “Сїчи”, а відтак поставив внесок, щоби "Просьвіта" підпирала їх дїяльність і закладанєм Сїчий ...”. Проте більшість членів філії “Просвіти” не підтримали його пропозицію щодо залучення просвітян в організації відкриття на територію краю нових осередків товариства "Січ",

Проте особливо небезпечною виявилася культурно-просвітницька робота з поширення в 1902-1903 р. у краї москвофільських ідей священика о. М. Семьонова, який “... дуже ворожо відноситься до руских (українських. $-A$. K.) інституций як і до рускої (української. $-A$. $K$.) інтелїгенциї взагалї, визиваючи єї в невідповідний спосіб підчас проповідий церковних",78.

Тому в 1902-1903 р. філія "Просвіти” здійснювала грунтовну перевірку (люстрацію) читалень та була на відкритті низки читалень товариства не тільки Коломийського філіального округу, але й сусідніх повітів. Зокрема, у квітні-червні 1902 р. члени філії товариства здійснили

\footnotetext{
${ }^{72}$ ЦДІАЛ України. Ф. 348. Оп. 1. Спр. 2942. Арк. 128-131.

73 Занепад Покутя. (Допись з Коломиї). Дїло. 1903. 10 (23) сїчня. Ч. 7. С. 2.

${ }^{74}$ Колесса О. Перестрій руских читалень на підставі зміни статута тов. "Просвіти”. Народ. 1890. 15 серпня. Ч. 16. С. 238-239; Чого хотять такъ зв. радикалы? Дюло. 1891. 17 (29) червня. Ч. 135. С. 1-2.

${ }^{75}$ Р. Я. Селяне на зборах “Просвіти” й “Общества Качковского”. Народ. 1890. 1 жовтня. Ч. 19. С. 285-286.

${ }^{76}$ Королько А. “Коломийське товариство Народних Спілок”: ідеологічні засади і практична діяльність іiі осередків на Покутті (кінець XIX - початок XX ст.). Питання історії України. Збірник наукових праць кафедри історії України Чернівецького національного університету імені Юрія Федьковича. Чернівці : Технодрук, 2014. Т. 17. С. 68-82.

${ }^{77}$ ЦДІАЛ України. Ф. 348. Оп. 1. Спр. 2943. Арк. 10 зв.

${ }^{78}$ Там само. Спр. 2942. Арк. 119.
} 
низку поїздок у населені пункти краю для піднесення просвітянського руху: у квітні О. Колодницький перебував у м. Кути Косівського повіту на відкритті відновленої читальні "Просвіти"; у травні-червні Л. Кузьма, О. Колодницький, Л. Кульчицький, І. Раковський і О. Печерський неодноразово перебували в с. Березів нижній, займаючись організацією створення нового осередку товариства; 5 червня Л. Кузьма, С. Винницький і І. Михалевський здійснювали перевірку читальні в с. Матіївці, а о. Гриньовський перебував з робочою поїздкою у м. Снятин; 15 червня Л. Кузьма, Іванець, Франчук і Кендзерський були на відкритті читальні у с. Молодятин; 19 травня у м. Коломиї для членів читалень товариства краю організовано просвітницько-господарське віче ${ }^{79}$. Станом на кінець 1902 р. під орудою філії товариства перебувало 32 читальні Коломийського філіального округу, в яких налічувалося 700 членів ${ }^{80}$.

У червні 1903 р. О. Колодницький здійснив люстрацію читальні в с. Шепарівці, Л. Кузьма, I. Михалевський і Є. Винницький перевіряли роботу просвітянського осередку в с. Молодятин, відпоручник о. А. Олесницький перебував на відкритті читальні “Просвіти" в містечку Гвіздець ${ }^{81}$. Однак ця робота ревізійного змісту була перервана у зв'язку з несподіваним переїздом голови філії товариства О. Колодницького до польського міста Дембіца: “Будучи отже занятий своєю справою, не міг він як слїд заниматись справою товариства, а тим самим і Видїл остався, так би сказати, без проводу. Втім настав час ферий (канікул. $-A$. $K$.), коли то майже всї

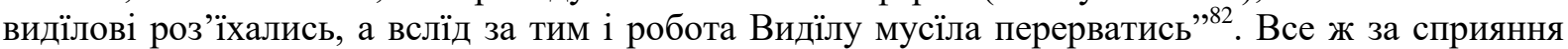
інших членів філії О. Кульчицького, Л. Кузьми, Є. Винницького і Н. Гриньовського за період жовтня 1903 р. - березня 1904 р. були відкриті нові читальні "Просвіти" в селах Воскресінці, Тростянка і Рунгури, відновлено роботу просвітянської “клітини” в с. Турка, з ревізійною метою організовані поїздки в села Корнич, Іспас та містечко Печеніжин ${ }^{83}$.

20 листопада 1908 р. на загальних зборах філії “Просвіти” в м. Коломия обраний новий керівний осередок: урядник I. Чернявський (голова), о. I. Майковський з с. Княждвір, професори Л. Кузьма, Р. Шипайло, Н. Даниш, Є. Данилович, А. Крушельницький, учитель І. Петришин, містянин Рудницький і селянин I. Ткачук з с. П'ядики ${ }^{84}$. Наступного дня, 21 листопада, відкрито нову (другу) читальню “Просвіти” ім. Тараса Шевченка при Руському (Українському) народному домі м. Коломия (перша діяла на "кутському передмісті" ${ }^{55}$ ), до складу якого ввійшло 80 членів. Головою читальні обраний проф. Ф. Примак. Цікаво, що одразу ж на другому поверсі Народного дому відкрита канцелярія філії товариства ${ }^{86}$. При читальні діяла "Міщанська спілка”, яка займалася піднесенням економічного рівня свідомості української громади міста. Культурно-просвітницький осередок мав добірну, проте не чисельну бібліотеку, “дає членам духову поживу і видирає з простих рук польські патріотичні видавництва". Читальня "Просвіти" зорганізувала аматорський драматичний гурток, який періодично ставив на сцені вистави. Загалом, у 1908 р. за сприяння філії товариства на території Коломийщини було відкрито сім читалень "Просвіти" - дві у с. Залуччя, по одній в с. Сороки, с. П'ядики, с. Рунгури і с. Мишин, а також при Руському (Українському) народному домі м. Коломия ${ }^{87}$.

21 грудня 1908 р. 3 нагоди 40-річчя заснування "Просвіти” в м. Коломия відбувся “ювілейний обхід” під керівництвом проф. Никифора Даниша ${ }^{88}$. Днем раніше подібний захід за сприяння членів коломийської філії та членів місцевої читальні організований у містечку

\footnotetext{
${ }^{79}$ ЦДІАЛ України. Ф. 348. Оп. 1. Спр. 2944. Арк. 13, 13 зв., 14.

${ }^{80}$ Там само. Арк. 14.

${ }^{81}$ Там само. Спр. 2943. Арк. 13 зв., 14.

82 Там само. Арк. 14.

${ }^{83}$ Там само. Арк. 14, 14 зв.

${ }^{84}$ Там само. Спр. 2942. Арк. 168, 168 зв.; Спр. 2943. Арк. 23, 23 зв.

${ }^{85}$ Там само. Спр. 2942. Арк. 70 зв., 71.

${ }^{86}$ Там само. Спр. 2941. Арк. 52, 53 зв.; 3 Коломиї. (А наша народна робота?). Дїло. 1909. 24 (11) лютого. Ч. 40. С. 2. Рубр.: Письма 3 краю.

${ }^{87}$ Там само. Спр. 2943. Арк. 20.

88 Там само. Спр. 2941. Арк. 52; Спр. 2942. Арк. 170; Спр. 2943. Арк. 18 зв.; 3 Коломиї. (Загальні збори філії “Просьвіти”...). Дїло. 1908. 1 грудня (18 падолиста). Ч. 271. С. 2. Рубр.: Письма $з$ краю.
} 
Печеніжин ${ }^{89}$. Члени філії І. Чернявський і Р. Шипайло взяли участь у роботі просвітницькоекономічного конгресу "Просвіти”, який відбувся 1-2 лютого 1909 р. у Львові ${ }^{90} .10$ червня 1909 р. спільно з місцевим осередком "Сільського господаря" філія "Просвіти” організувала у м. Коломиї просвітницько-економічне віче ${ }^{91}$ Саме за безпосередньою участю керівництва “Сільського господаря" філія "Просвіти" купила у коломийського міщанина Габера будинок 3 господарськими приміщеннями "за 1200 крон для читальні і промислової бурси по вул. Гетьманській, 53. Головний виділ "Просвіти" у м. Львів виділив 300 к., решта суми була зібрана 3 членів філії та з пожертв міщан ${ }^{93}$.

У 1909 р. філія “Просвіти” організувала з'їзд народних вчителів. На ньому обговорювалися справи української народної школи і учительства, діяльність вчителів в українських народних організаціях, правовий захист вчителів, справа організації учительських і шкільних віч. На з'їзд були запрошені представники українських політичних організацій, Руського (Українського) педагогічного товариства і Головної управи товариства "Взаємної допомоги вчителям"94.

За одинадцять місяців - грудня 1908 р. - жовтня 1909 р. - члени філії товариства здійснили 36 поїздок до 31 читальні Коломийського філіального округу, лише у м. Печеніжин було проведено таких п'ять зустрічей, а в с. Коршів - дві. За цей період часу зусиллями керівництва товариства було відкрито шість читалень у селах Раківчик, Рогиня (нині село Городенківського району Івано-Франківської обл.), Назірна, Гуцулівка Коломийського повіту, Ключів великий Печеніжинського повіту, а також, як уже зазначалося, у м. Коломиї читальня при Руському (Українському) народному домі ${ }^{95}$, який, через брак приміщення, був об'єднаний в одну читальню на "кутському передмісті". Загалом, на кінець 1909 р. до коломийської філії "Просвіти" належало 49 читалень ${ }^{96}$. У проміжку часу з 1 листопада 1909 р. до 12 червня 1910 р. просвітяни філіального осередку з різноманітними цілями (участь у роботі загальних і “довірочних” зборів, відкритті і перевірці читалень; виступи з просвітницько-економічними рефератами) здійснили 25 поїздок у населені пункти краю, відкрили три нові читальні у селах П'ядики, Джурків і Березів вижний (друга читальня “на Лазах")

Восени 1910 р. філія “Просвіти” організувала курси для неграмотних жителів краю ${ }^{98}$. Протягом 1909-1914 рр. філія утримувала учнів ремісничо-промислової бурси в м. Коломия, якщо їхні батьки або опікуни були членами "Просвіти",. За словами просвітян, мета ії створення - "виховати в патріотичнім дусї молодїж тутешніх шкіл ремісничо-промислових, як також рятувати іï перед польонїзациєю і московщенєм, до чого подали собі руки так тутешні польонїзатори як і руссифікатори"100. У вересні 1909 р. члени філії товариства взяли на опіку 13 вихованців бурси, 3 яких 11 навчалися у школі деревного промислу та по одному - у гончарській та в народній школі ${ }^{101}$. Настоятелем бурси став просвітянин Іван Петришин. 3 метою виховання української молоді в національному дусі, члени філії товариства взяли на себе обов’язок викладати для своїх підопічних історію Руси-України та історію русько-української писемності (історію української літератури). Вони звернулися до керівництва "Просвіти" 3

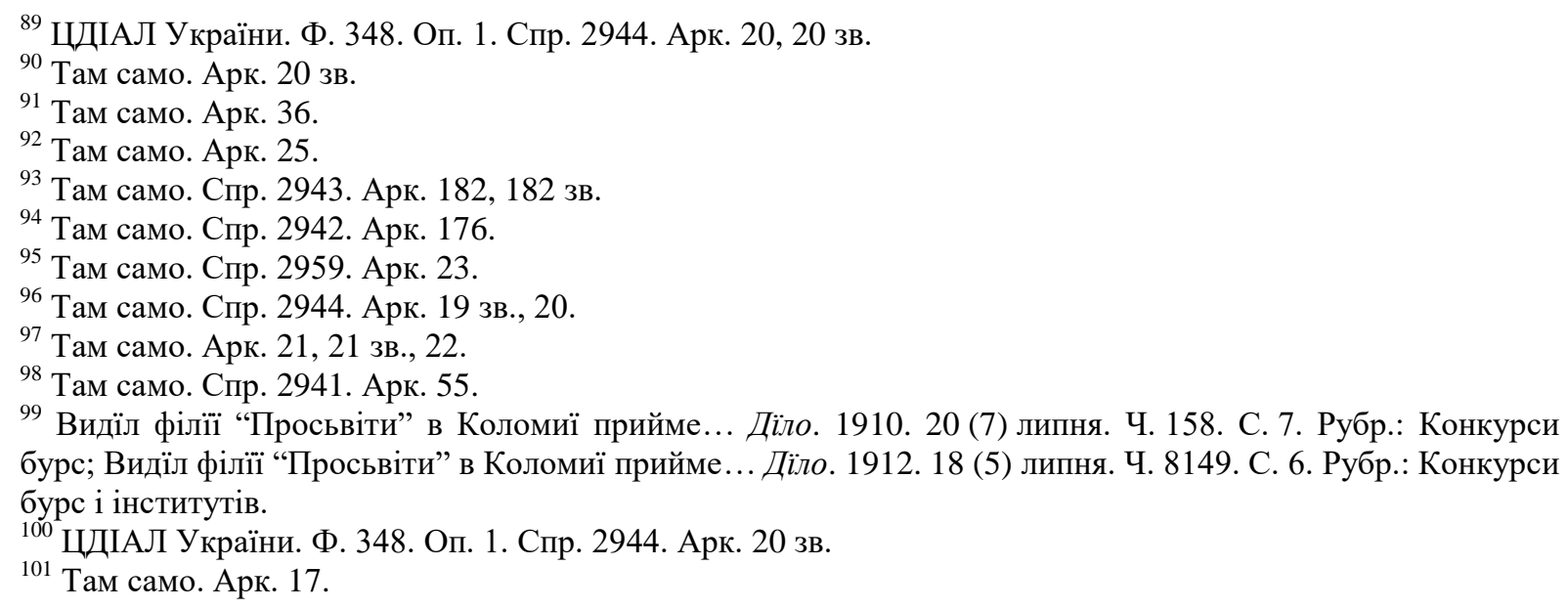


проханням подарувати для вихованців ремісничо-промислової бурси 12 книг "Історії УкраїниРуси" О. Барвінського, по одному примірнику "Руської письменності" Ю. Романчука, мапу України-Руси, укладену д-ром Величком ${ }^{102}$. В 1913 р. керівний осередок “Просвіти” Коломийського повіту оголосив конкурс на отримання двох стипендій по 50 кор. для учнів, які мали бажання навчатися на 5-місячних зимових курсах садівничо-господарської школи в с. Милування Товмацького повіту (нині село Тисменицького району Івано-Франківської обл.) ${ }^{103}$.

За вказівкою керівництва у м. Львів з початком другого десятиліття XX ст. до філії товариства у м. Коломиї почали надсилати звіти про свою діяльність читальні "Просвіта" населених пунктів Коломийського повіту. Так, у червні 1910 р. звіти про свою діяльність надіслали лише вісім читалень: сіл Гуцулівка, Залуччя над Прутом, Кулачківці (нині село Снятинського району Івано-Франківської обл.), Матіївці, Пилипи, Раківчик, Росохач, а також передмістя Надвірнянське м. Коломия ${ }^{104}$.

У 1911 р. обраний новий керівний склад філії “Просвіти” у м. Коломия: Іван Чернявський (голова), Іван Фіголь (заступник голови), Іван Петришин (секретар), Іван Біленький (касир), Іван Рудницький (контролер), Євген Данилович, Іван Ткачук, А. Миколаєвич, Теодор Примак, Михайло Гудз ${ }^{105}$. За цей рік філія “Просвіти": провела 33 засідання; мала власну канцелярію, бібліотеку, яка складалася з 302 томів книг; опікувалася 20 вихованцями ремісничо-промислової бурси, яка знаходилася у приміщенні товариства; влаштувала величаві урочистості 3 нагоди сторіччя Маркіяна Шашкевича (8 грудня) ${ }^{106}$, поставила два концерти для вихованців бурси; організувала два з'їзди відпоручників (делегатів) читалень та здійснила 26 люстрацій (перевірок) осередків "Просвіти" у Коломийському повіті; спричинилася до заснування читальні “Просвіти” у с. Дятьківці та “Молочарської спілки” у с. Турка. На 87 громад Коломийського філіального округу: діяли 54 читальні, з яких 42 розвивалися добре, вісім знаходилися у задовільному стані і лише чотири занепадали; загальна кількість членів читалень -2509 , з них 2207 чоловіків і 302 жінок; передплачувалося 173 часописи, у бібліотеках читалень налічувалося 5341 книга. Власні читальняні будинки мали лише шість осередків товариства (у селах Балинці, Вербіж нижній, Жукотин, Іспас, Корнич, Сопів), каси - один, крамниці - сім, шпихліри - один. У двох читальнях функціонували аматорські театральні гуртки, у п'яти хорові колективи. У селах Коломийщини організовано 14 шевченківських і 18 шашкевичівських “обходів" (урочистостей з нагоди вшанування Т. Шевченка і М. Шашкевича) ${ }^{107}$. У середині 1912 р. філія “Просвіти” спільно з філією “Сільського господаря” були організаторами проведення виставки домашнього промислу ${ }^{108}$.

У передвоєнний рік, 25 березня 1913 р., на загальних зборах філії “Просвіти” обраний новий керівний склад товариства: голова - професор Євген Данилович, заступник голови професор гімназії Теодор Примак, секретар - студент Петро Білоскурський, касир - учитель Іван Біленький, члени виділу - урядовці Михайло Гудз, Юліан Колцуняк та учитель Іван Матковський, заступники - гімназійний професор Никифор Даниш, студент Петро Марчишин і містянин Іван Рудницький ${ }^{109}$.

Коротко звернемо увагу про створення під орудою філії двох читалень "Просвіти” у м. Коломия - на "кутському передмісті" та імені Тараса Шевченка.

21 січня 1900 р. (за іншими даними 28 листопада 1899 р. ${ }^{110}$ ) за участю керівництва філії товариства відбулося відкриття читальні “Просвіти” на “кутському передмісті" у м. Коломия

\footnotetext{
102 ЦДІАЛ України. Ф. 348. ОП. 1. Спр. 2942. Арк. 177, 177 зв.

103 Видїл філії Тов. “Просьвіта” в Коломиї розписує конкурс... Свобода. Ілюстрована полїтична і просьвітна часопись. 1913. 18 вересня. Ч. 38. С. 7. Рубр.: Оповістки.

${ }^{104}$ ЦДІАЛ України. Ф. 348. Оп. 1. Спр. 2942. Арк. 184.

105 Там само. Спр. 2944. Арк. 32.

106 Там само. Спр. 2942. Арк. 194.

107 Там само. Спр. 2942. Арк. 191; Спр. 2944. Арк. 32, 32 зв., 33, 35.

108 Там само. Спр. 2942. Арк. 202 зв.

109 Там само. Спр. 2943. Арк. 32.

${ }^{110}$ Бойцан В. Читальня ... С. 42.
} 
(суч. вул. Міцкевича, 47 в). 3 привітанням виступив голова філії Володимир Глинський, вказавши на важливість створення цього культурно-просвітницького осередку та заохотивши зібраних членів-засновників до праці, ощадності, стійкості у реалізації своїх намірів щодо заснування позичкових кас, шпихлірів і т. д. Його підтримав член філії товариства О. Кульчицький, наголосивши на необхідності ведення економічно-просвітницької праці, адже торгівля і промисел потрапили у чужі руки, а "цїлий наш доробок, наш гріш кервавий переходить в чужу кишеню”. До складу читальні ввійшло 34 члени, обрано його керівництво: о. Теодозій Курпяк (голова), Леонтій Кузьма (заступник голови), Микола Жураковський, Василь Березовський, Антоній Базак, Антоній Березовський, Петро Яремчук, Стефан Жураковський, Омелян Колодницький ${ }^{11}$.

2 січня 1910 р. відбулися загальні збори осередку, на якому про важливість створення українських кооперативних спілок промовляли представник коломийської філії Н. Даниш та о. Станецький. Обраний новий керівний осередок читальні: О. Кігітчук (голова) (згідно звіту читальні "Просвіти", переданого до м. Львів, головою осередку був I. Рудницький $\left.{ }^{12}\right)$, М. Березовський (заступник голови), І. Рудницький (писар), І. Судак (скарбник), В. Данилюк (бібліотекар), П. Божемська, Розалія Базак. Просвітяни збирали кошти на будівництво власного читальняного будинку. Осередок товариства налічував 73 члени, мав змішаний хор, що складався з 30 хористів, аматорський гурток та невеличку бібліотеку, в якій містилося 260 книг, переважно видання "Просвіти"113.

Читальня "Просвіти" імені Тараса Шевченка, яка була заснована у листопаді 1908 р., налічувала 80 членів - 60 чоловіків і 20 жінок. До складу керівного осередку входили: Федір Примак (голова), Осип Кігітчук (заступник голови), Юліан Колцуняк (писар), Осип Турянський (касир), Іван Хомяк (бібліотекар), Стефан Ясінчук і Михайлина Рудницька. Цей культурнопросвітницький осередок, за словами краєзнавця Володимира Бойцана, відігравав чи не найважливішу роль в культурному житті міста ${ }^{114}$. У читальні містилася невелика бібліотека 3 36 книг, передплачувалися українські часописи “Свобода" і “Письмо з Просьвіти". Оренда кімнат Руського (Українського) народного дому виявилася за дорогою, а тому читальня “Просвіти” імені Тараса Шевченка у травні 1909 р. об'єдналася з читальнею на “кутському передмісті" і знаходилася у приміщенні останньої ${ }^{115}$.

У кінці 1908 р. відбулися загальні збори читальні, на яких обрали новий провід: голова Іван Рудницький, його заступник - Матвій Березовський, члени: писар - Павлина Божемська, касир - Іван Судак, бібліотекар - Василь Данилюк та заступниця виділових - Розалія Базак. Рівень освіченості читальників був доволі високий, тільки шість були малописьменними. Збори читальні "Просвіти" імені Тараса Шевченка супроводжувалися рефератами на національнопатріотичну тематику. Доповідачами були відомі коломийські інтелектуали: Й. Чайківський, Ф. Примак, Р. Шипайло та ін. Функціонував аматорський театральний гурток та хор з 30 співаків. Поступово зростала читальняна бібліотека, яка на початку лютого 1910 р. нараховувала 260 творів у 98 томах. При осередку зав'язали міщанську торгово-промислову спілку з обмеженою порукою, з якої користали не тільки читальники, але й містяни ${ }^{116}$.

Таким чином, напередодні Першої світової війни в м. Коломия окрім філії “Просвіти", функціонували дві читальні - при Руському (Українському) народному домі ім. Тараса Шевченка і на "кутському передмісті". Також діяли такі українські культурно-освітні, кооперативні і господарські товариства: "Родина" (1889 р. заснування, 96 членів), “Жіночий кружок” (утримував жіночу бурсу, надавав дешеві обіди для незабезпечених школярів), “Кружок українських дівчат”, “Народний дім”, музично-хорове товариство “Коломийський Боян” (59 членів), “По-

\footnotetext{
${ }^{111}$ ЦДІАЛ України. Ф. 348. Оп. 1. Спр. 2959. Арк. 9, 9 зв.

112 Там само. Арк. 20.

113 Там само. Арк. 14; Присутний. 3 Коломиї. (Читальня “Просьвіти” на кутськім передмістю). Свобода.

Полїтична, просьвітна і господарська часопись. 1910. 20 сїчня. Ч. 3. С. 5-6. Рубр.: Дописи.

114 Бойцан В. Читальня... С. 42.

115 ЦДІАЛ України. Ф. 348. Оп. 1. Спр. 2944. Арк. 20; Спр. 2959. Арк. 35, 35 зв.

${ }^{116}$ Бойцан В. Читальня... С. 42.
} 
кутський союз кредитовий”, академічне товариство “Громада”, філія “Сільського господаря”, кредитне товариство "Міщанська спілка", “Шкільна поміч”, гімнастичне товариство “Сокіл” (69 членів), “Руська захоронка”, філія Руського товариства педагогічного (члени цього товариства: утримували бурсу для учнів руської (української) гімназії; вели семінарійні курси для хлопців і дівчат, а також курси для неграмотних; спробували заснувати курси для неграмотних солдат, але заборонило військове командування), окружний відділ товариства “Взаїмна поміч учителів і учительок” (утримував бурсу для хлопців; при відділі функціонував “Аматорський драматичний кружок" і працювала бібліотека) ${ }^{117}$.

Отже, “Просвіта" несла в народні маси культуру, знання й національну свідомість і була важливим чинником консолідації галицьких українців. Діяльність культурно-просвітницького товариства регламентувалася статутами. Офіційні документи першої половини 1890-х рр. чітко засвідчують, що у своїй роботі на місцях головний осередок “Просвіти” у м. Львів спирався на філії та читальні. Філія “Просвіти” у м. Коломия, як складова просвітницького руху, відіграла важливу роль у піднесенні національної свідомості українців. Її практичні кроки у кінці XIX на початку XX ст. стали основним засобом впливу на суспільну думку та підняття культурного рівня жителів краю. Окрім цього, філія виконувала й інше завдання: виявлення в міському і сільському середовищі людей, здатних до розумової праці, залучення їх до суспільно-політичної діяльності з перетворенням у подальшому на провідників нації. За безпосередньої участі iii кращих представників стало можливим створення у читальнях драматичних гуртків, оркестрів, бібліотек, крамниць і позичкових кас. Члени філії товариства "Просвіта" регулярно проводили у м. Коломия та селах краю просвітницько-економічні віча, відкриті лекції, урочисті заходи з нагоди вшанування Т. Шевченка і М. Шашкевича. Завдяки активній діяльності філії товариства на початку XX ст. в головному місті Покуття були засновані і діяли дві читальні "Просвіта" - на “кутському передмісті” та імені Тараса Шевченка.

\title{
ACTIVITIES AFFILIATE OF THE "PROSVITA" IN THE TOWN KOLOMYIA (late XIXth - early XXth centuries)
}

\author{
Andrii KOROLKO \\ State Higher Educational Institution \\ "Vasyl Stefanyk Precarpathian National University", \\ Department of History of Ukraine and methods of teaching history, \\ Shevchenko St., 57, 76018, Ivano-Frankivsk, Ukraine, \\ e-mail:_korolko_andr@ukr.net
}

\section{Summary}

The article analyzes the activities affiliate of the "Prosvita" in Kolomyia (late XIX $X^{\text {th }}-$ early $X X^{\text {th }}$ centuries).

The statutes of "Prosvita" concerning organization of activity affiliates and reading rooms of the company are analyzed. Affiliates and reading rooms of "Prosvita" were to become centers of cultural revival for Ukranians of the Austro-Hungarian Empire.

Forms of work and practical steps of activity affiliate of the "Prosvita" in Kolomyia in the investigated period are traced. The affiliate of the "Prosvita" was formed on the foundations of the Ukrainian literary and drama society and the local reading room. The center of the society was opened on February 27, 1877. Its first chairman was Ivan Levitsky. For the first decade, the affiliate did not show much activity in the development of national and cultural life of Ukrainians in the region.

The rise of the society dates back to the last decade of the XIX ${ }^{\text {th }}$ century. The affiliate regularly organized cultural, educational and artistic events and prepared reports on its work.

The practical work of the society became more active at the beginning of the $X X^{\text {th }}$ century. Members of the affiliate organized educational and economic councils, organized concerts in honor of the memory of T. Shevchenko and M. Shashkevich, gave scientific and educational lectures, opened new reading rooms of the

\footnotetext{
117 Часть інформацийна. Провідник по Галичинї. Ілюстрований калєндар товариства “Просьвіта” на рік звичайний 1910. Львів, 1910. Річник ХХXIII. С. 29.
} 
"Prosvita" in the region. However, there were difficulties in the work of the society in connection with the activities of the reading rooms of the M. Kachkovskyi Society and the "Kolomyia society of People's Unions", which were in the path of influence of muscovites and radicals.

The activity of two reading rooms of the "Prosvita" in Kolomyia - in the "Kutsky suburb" and named after Taras Shevchenko is covered.

The affiliate of the "Prosvita" in Kolomyia has become the main means of influencing public opinion and raising the cultural level of the region's residents. Its members found in the urban and rural environment people capable of intellectual work, involved in socio-political activities with the subsequent transformation into leaders of the Ukrainian nation.

Keywords: affiliate, "Prosvita”, reading room, Pokuttia, cultural and educational work, library.

\section{REFERENCES}

A. L. (1900, Marsh 3 (16)). Z Kolomyi pyshut nam ... [From Kolomyia write to us ...]. Dilo, no. 51, pp. 2-3 (in Ukrainian).

Arsenych, P. (1997). Filiia "Prosvity" v Kolomyi [Affiliate of "Prosvita" in Kolomyia]. Biuleten IvanoFrankivskoho OO VUT “Prosvita” im. T. Shevchenka, no. 10, pp. 7 (in Ukrainian).

Az Buky. (1894, December 2 (14)). Z Kolomyi pyshut nam ... [From Kolomyia write to us ...]. Dilo, no. 270, pp. 3-4 (in Ukrainian).

Boitsan, V. (2001). Chytalnia [Reading room]. Entsyklopediia Kolomyishchyny [Encyclopedia of Kolomyishchyna]. Kolomyia: Vik, Pt. 12, let. Ch, pp. 38-45 (in Ukrainian).

Bratia Zemliaky pokutskoi Rusy-Ukrainy! [Brothers of the countrymen of Pokutian Rus-Ukraine!]. (1901). Dilo, October 8 (21), no. 225 and 226, s. 3 (in Ukrainian).

Central State Historical Archive of Ukraine, Lviv. F. 348 "Prosvita” Society, Lviv. Descr. 1 Case. 2941 (Lists of members the affiliate in Kolomyia). 1880-1916. 68 p. (in Ukrainian).

Central State Historical Archive of Ukraine, Lviv. F. 348. Descr. 1 Case. 2942 (Correspondence with the affiliate in Kolomyia about holding meetings, conferences, approval of statutes and other organizational issues). 1889-1913. 223 p. (in Ukrainian).

Central State Historical Archive of Ukraine, Lviv. F. 348. Descr. 1 Case. 2943 (Protocols of meetings and general meetings of members of the affiliate in Kolomyia). 1897-1938. 115 p. (in Ukrainian).

Central State Historical Archive of Ukraine, Lviv. F. 348. Descr. 1 Case. 2944 (Reports on the activities of the affiliate in Kolomyia). 1899-1939. 140 p. (in Ukrainian).

Central State Historical Archive of Ukraine, Lviv. F. 348. Descr. 1 Case. 2953 (Reports, protocols, correspondence and other materials on the activities of the reading room named after T. Shevchenko in Kolomyia). 1899-1937. 76 p. (in Ukrainian).

Chast informatsyina. Providnyk po Halychyni [Information part. Guidebook to Galicia] (1910). Iliustrovanyi kaliendar tovarystva "Prosvita" na rik zvychainyi 1910. Lviv, Annual XXXIII, p. 29 (in Ukrainian).

Choho khotiat tak zv. radykaly? [What do the so-called radicals want?]. (1891, June 17 (29)). Dilo, no. 135, pp. 1-2 (in Ukrainian).

Do Rusyniv z povitiv: Kolomyiskoho, Sniatynskoho, Kosivskoho, Horodenskoho i susidnykh [To the Ruthenians from the counties: Kolomyia, Sniatyn, Kosiv, Gorodenka and neighboring]. (1890, August 3 (15)). Dilo, no. 175, p. 1 (in Ukrainian).

Filii "Prosvity". 10. Filiia "Prosvity" v Kolomyi [Affiliates of "Prosvita". 10. The affiliate of "Prosvita" in Kolomyia]. (1903). Zvit z diialnosty Tovarystva "Prosvita" za chas vid 1. sichnia 1902 do 31. hrudnia 1903. Lviv : Z drukarni Naukovoho Tovarystva imeny Shevchenka [Report on the activities of the Society "Prosvita" for the period from January 1, 1902 to December 31, 1903]. Lviv: Z drukarni Naukovoho Tovarystva imeni Shevchenka, pp. 16-17 (in Ukrainian).

Filii "Prosvity". 7. Filiia v Kolomyi ... [Affiliates of "Prosvita". 7. The affiliate in Kolomyia ...]. (1900). Spravozdanie z diialnosty Tovarystva "Prosvita" za chas vid 1. sichnia 1898 do 31. hrudnia 1899 [Report on the activities of the Society "Prosvita" for the period from January 1, 1898 to December 31, 1899]. Lviv: Z drukarni Naukovoho Tovarystva imeny Shevchenka, pp. 13-14 (in Ukrainian).

Filiia "Prosvity" v Kolomyi [The affiliate of "Prosvita" in Kolomyia]. (1902, May 11 (24)). Dilo, no. 105 , p. 2 (in Ukrainian).

Filiia "Prosvity" v Kolomyi, ustroiuie dnia 22 n. st. marta s. r. velykyi sviatochnyi obkhid v chest Tarasa Shevchenka ... [The affiliate of "Prosvita" in Kolomyia organizes a big festive procession in honor of Taras Shevchenko on March 22 ...]. (1900, February 24 (March 8)). Svoboda. Politychne, prosvitne i hospodarske pysmo dlia narodu, no. 8, p. 4 (in Ukrainian). 
Harat, R. M. (2000). Filiia "Prosvity" v Kolomyi v dokumentakh Tsentralnoho derzhavnoho istorychnoho arkhivu v Lvovi [The affiliate of "Prosvita" in Kolomyia in the documents of the Central State Historical Archive in Lviv]. Pytannia istorii Ukrainy, vol. 4, pp. 377-382 (in Ukrainian). Ukrainian).

II. Filii "Prosvity" [II. Affiliates of "Prosvita"]. (1904, May 12 (25)). Dilo, no. 105, pp. 1-2 (in

Kolessa, O. (1890, August 15). Perestrii ruskykh chytalen na pidstavi zminy statuta tov. "Prosvity" [Restructuring of Ukrainian reading rooms on the basis of changes in the charter of the society "Prosvita"]. Narod, no. 16, pp. 238-239 (in Ukrainian).

Kolomyiske sviato [The Kolomyia holiday]. (1901, October 20 (November 2)). Dilo, no. 287, pp. 2-3 (in Ukrainian).

Korolko, A. (2014). "Kolomyiske tovarystvo Narodnykh Spilok": ideolohichni zasady i praktychna diialnist yii oseredkiv na Pokutti (kinets XIX - pochatok XX st.) ["Kolomyia society of People's Unions": ideological principles and practice of its branches in Pokuttia (late $\mathrm{XIX}^{\text {th }}-$ early $\mathrm{XX}^{\text {th }}$ centuries)]. Pytannia istorii Ukrainy, vol. 17, pp. 68-82 (in Ukrainian).

Korolko, A. (2018). Diialnist oseredkiv tovarystva "Prosvita" na Pokutti naprykintsi XIX - pochatku XX st. (za materialamy chasopysu "Dilo") [Activity of cells of "Prosvita" in Pokuttia at the late XIXth - early XXth centuries (based on "Dilo" newspaper)]. Pokuttia - kolyska ukrainskoho natsionalnoho derzhavotvorennia, Ivano-Frankivsk, pp. 237-266 (in Ukrainian).

Korolko, A. (2019). Statuty "Prosvity" - holovnyi chynnyk orhanizatsii diialnosti filii i chytalen ukrainskykh kulturno-prosvitnikh tovarystv v Halychyni (ostannia tretyna XIX - pochatok XX st.) [Statues of "Prosvita" - the main factor in organizing the activties of affiliates and reading rooms of Ukrainian cultural and associations in Galicia (last third XIX ${ }^{\text {th }}$ - early $\mathrm{XX}^{\text {th }}$ centuries)]. Kaluski istorychni studii, vol. 3, pp. 29-41 (in Ukrainian).

Kryhulets, M. (1902, March 15 (28)). Ohliad narodnoi roboty v Kolomyishchyni (Dopys) [Review of folk work in the Kolomyia County (Post)]. Dilo, no. 61, p. 2 (in Ukrainian).

Monolatii, I. (2010). Tsisarska Kolomyia. 1772-1918 [Imperial Kolomyia. 1772-1918]. IvanoFrankivsk: Lileia-NV (in Ukrainian).

Narodne sviato Pokutskoi Rusy [People's holiday of Pokutian Rus']. (1901, November 7 (October 25)). Svoboda. Politychne, prosvitne i hospodarske pysmo dlia narodu, no. 43, p. 2 (in Ukrainian).

Novyi statut Tovarystva "Prosvita" [The new charter of "Prosvita"]. (1891, March 22 (April 3)). Batkivshchyna, no. 12, pp. 72 (in Ukrainian).

Pershii ustav dlia Chytalen "Prosvity" ukhvalenyi Holovnym Vydilom tovarystva "Prosvita" u Lvovi dnia 24 n. st. sichnia $1894 \mathrm{r}$. [The first charter for reading rooms of "Prosvita" of the approved by the headquarters in Lviv of January 24, 1894]. (1894, January 19 (31)). Dilo, no. 14, pp. 1-2 (in Ukrainian).

Promova holovy tovarystva "Prosvita" Yul. Romanchuka na zahalnykh zborakh [Speech of the chairman of the society "Prosvita" Yul. Romanchuk at the general meeting]. (1898, January 22 (February 3)). Dilo, no. 17, p. 1 (in Ukrainian).

Prysutnyi. (1910, Yanuary 20) Z Kolomyi. (Chytalnia "Prosvity" na kutskim peredmistiu) [From Kolomyia. (Reading room of "Prosvita" in the Kutsk suburb)]. Svoboda. Politychna, prosvitna i hospodarska chasopys, no. 3, pp. 5-6 (in Ukrainian).

Pysmo z Kolomyi. (Prosvitno-ekonomichne viche kolomyiskoi filii "Prosvity") [Letter from Kolomyia. (Educational and economic chamber of the Kolomyia affiliate of "Prosvita")]. (1899, 1900). Dilo, no. 286, p. 2 (in Ukrainian).

R. Ia. (1890, October 1). Seliane na zborakh "Prosvity" i "Obshchestva Kachkovskoho" [Peasants at the meeting of "Prosvita" and "Kachkovsky Society"]. Narod, no. 19, pp. 285-286 (in Ukrainian).

Reguliamin i instruktsyia dlia vydilu filii "Prosvity" [Rules and instructions for affiliate management of "Prosvita"]. (1908, June 5, May 23). Dilo, no. 124, pp. 2-3 (in Ukrainian).

Satyr, O. (1900, March, 3(16)). Z Kolomyi (Populiarno-naukovi vyklady kolomyiskoi filii "Prosvity") [From Kolomyia (Popular scientific lectures of the Kolomyia affiliate of "Prosvita")]. Dilo, no. 51, p. 2 (in Ukrainian).

Savchuk, M. (2018). Prosvitiany Halychyny zikhalysia do Kolomyi. Slovo Prosvity. Retrieved from: http://slovoprosvity.org/2018/12/06/prosvityany-halychyny-zjihalysya-do-kolomyji (in Ukrainian).

Serediak, A. (1993). Diialnist tovarystva "Prosvita" v 1868-1914 rr. [The activities of "Prosvita" in 1868-1914], Narys istorii “Prosvity”. Krakiv, Paryzh, Lviv, pp. 18-42 (in Ukrainian).

Sorok lit diialnosty "Prosvity" [Forty years of activity of the "Prosvita"]. (1908, December 8 (November 25)). Dilo, no. 276, pp. 1-2 (in Ukrainian).

Spravozdanie Narodnoho Komitetu. (Dalshe) [Report of the Peoples Committee. (Continuation)]. (1900, June 28 (July 11)). Dilo, no. 144, p. 2 (in Ukrainian). 
Spravozdanie z diialnosty tovarystva "Prosvita" za chas vid 1 sichnia $1894 \mathrm{r}$. do 31 hrudnia $1895 \mathrm{r}$. [Report on the activities of the society of "Prosvita" for the period from January 1, 1894 to December 31, 1895]. (1896, January 5 (17)). Dilo, no. 4, p. 2 (in Ukrainian).

Spravozdanie z diiatelnosty Tovarystva "Prosvita" za chas vid 1 sichnia 1892 do 31 hrudnia 1893 roku [Report on the activities of the society of "Prosvita" for the period from January 1, 1892 to December 31, 1893]. (1894, January 15 (27)). Dilo, no. 11, pp. 1-2 (in Ukrainian).

Spravy soimovi [Tne sejm affairs]. (1890, October 24 (November 5)). Batkivshchyna, no. 43 and 44, pp. 542-543 (in Ukrainian).

Tovarystva dlia pidderzhky tovaryskoho i narodnoho zhytia. I. Pershe ruske literaturno-dramatychne tovarystvo $\mathrm{v}$ Kolomyi [Societies for the support of social and people's life. I. The first Ukrainian literary and dramatic society in Kolomyia]. (1885). Iliustrovanyi kaliendar tovarystva "Prosvita" na rik zvychainyi 1886. Lvov, pp. 84-85 (in Ukrainian).

V kolomyiskim poviti [In the Kolomyia district]. (1899, May 18 (6)). Svoboda. Pysmo politychne, prosvitne y hospodarske dlia narodu, no. 19, p. 150 (in Ukrainian).

V kolomyiskim poviti: Zahalni zbory filii tovarystva "Prosvita" v Kolomyi vidbuly sia ... [In the Kolomyia district: The general meeting affiliate of the "Prosvita" in Kolomyia took place ...]. (1899, June 25 (Juli 7)). Svoboda. Pysmo politychne, prosvitne y hospodarske dlia narodu, no. 26, p. 206 (in Ukrainian).

Viche v Kolomyi [Chamber in Kolomyia]. (1899, November 11 (23)). Svoboda. Pysmo politychne, prosvitne y hospodarske dlia narodu, no. 46, p. 367 (in Ukrainian).

Vid vydilu. Vydil chytalni v Yspasi pobich Kolomyi skladaie ... [From management. The management of the reading room in Ispas near Kolomyia is ...]. (1896, August 30 (September 11)). Dilo, no. 195, p. 3 (in Ukrainian).

Vydil filii "Prosvity" v Kolomyi pryime ... [The management affiliate of "Prosvita" in Kolomyia will accept .... . (1910, July 20 (7)). Dilo, no. 158, p. 7 (in Ukrainian).

Vydil filii "Prosvity" v Kolomyi pryime ... [The management affiliate of "Prosvita" in Kolomyia will accept ...]. (1912, July 18 (5)). Dilo, no. 8149, p. 6 (in Ukrainian).

Vydil filii Tov. "Prosvita" v Kolomyi rozpysuie konkurs ... [The management affiliate of "Prosvita" in Kolomyia is announcing a competition ...]. (1913, September 18). Svoboda. Iliustrovana politychna i prosvitna chasopys, no. 38, p. 7 (in Ukrainian).

Vydil kolomyiskoi filii "Prosvity" povidomliaie ... [The management of the Kolomyia affiliate of "Prosvita" reports ...]. (1903, March 5 (18)). Dilo, no. 52, p. 2 (in Ukrainian).

Vydil tovarystva "Prosvity" na poslidnim svoim zasidaniu ukhvalyv pozhertvuvaty na ruky "Shkilnoi Pomochy" v Kolomyi ... [At its last meeting, the affiliate of "Prosvita" decided to donate to the "School Assistance" in Kolomyia .... . (1892, September 4 (16)). Batkivshchyna, no. 36, p. 180 (in Ukrainian).

Vydil tovarystva "Prosvity" zaraz po Zahalnykh Zborakh tovarystva v Kolomyi zazhadav od uriadu pochtovoho rozslidzhenia ... [The affiliate of the society of "Prosvita" now on General meeting of the society in Kolomyia demanded from the government of postal investigation ...]. (1890, August 28 (September 9)). Dilo, no. 194, p. 1 (in Ukrainian).

Z Kolomyi [From Kolomyia]. (1901, May 9 (April 26)). Svoboda. Politychne, prosvitne i hospodarske pysmo dlia narodu, no. 17, pp. 2-3 (in Ukrainian).

Z Kolomyi pyshut nam ... [From Kolomyia write to us ...]. (1899, May 21 (June 1)) Svoboda. Pysmo politychne, prosvitne y hospodarske dlia narodu, no. 21, p. 166 (in Ukrainian). Ukrainian).

Z Kolomyi pyshut nam ... [From Kolomyia write to us ...]. (1898, March 7 (19)). Dilo, no. 53, p. 2 (in

Z Kolomyi. (A nasha narodna robota?) [From Kolomyia. (And our people's work?)]. (1909, February 24 (11)). Dilo, no. 40, p. 2 (in Ukrainian).

Z Kolomyi. (Zahalni zbory filii "Prosvity" ...) [From Kolomyia. (General meeting the affiliate of "Prosvita" ...)]. (1908, December 1 (November 18)). Dilo, no. 271, p. 2 (in Ukrainian).

Z Kolomyi. Programa kontsertu Shevchenka ustroiuvanoho zakhodom vsikh ruskykh tovarystv dnia 30 maia ... [From Kolomyia. The program of Shevchenko's concert organized by the event of all Ukrainian societies on May 30 .... . (1901, May 15 (28)). Dilo, no. 107, p. 3 (in Ukrainian).

Z Kolomyi. Vydil kolomyiskoi filii "Prosvity" opovishchuie ... [From Kolomyia. The management of the Kolomyia affiliate of "Prosvita" notifies ...]. (1901, March 3 (16)). Dilo, no. 50, p. 3 (in Ukrainian).

Zahalni zbory kolomyiskoi filii "Prosvity"... [General meeting of the Kolomyia affiliate of "Prosvita"...]. (1894, May 30 (June 11)). Dilo, no. 120, p. 3 (in Ukrainian).

Zahalni Zbory tovar. Prosvita [General meeting of "Prosvita"]. (1890, August 11 (23)). Dilo, no. 181, p. 1 (in Ukrainian). 
Zahalni Zbory tovar. Prosvita. (Konets) [General meeting of "Prosvita". (The end)]. (1890, august, 13 (25)). Dilo, no. 182, p. 1 (in Ukrainian).

Zahalni Zbory tovarystva "Prosvity" v Kolomyi [General Meeting of the society of "Prosvita" in Kolomyia]. (1890, August 18 (30)). Dilo, no. 186, August 30 (September 1), no. 187, pp. 1-2 (in Ukrainian).

Zahalni Zbory tovarystva "Prosvity" v Kolomyi [General Meeting of the society of "Prosvita" in Kolomyia]. (1890, August 24 (September 5)). Batkivshchyna, no. 34 and 35, September 7 (19), no. 37, September 21 (October 3), no. 38 and 39, pp. 435-441, 466-469, 482-484 (in Ukrainian).

Zanepad Pokutia. (Dopys z Kolomyi) [Decline of Pocuttia. (Letter from Kolomyia)]. (1903, yanuary, 10 (23)). Dilo, no. 7, p. 2 (in Ukrainian).

Zuliak, I. (2010). Rol "Prosvity" u poshyrenni ekonomichnykh znan u Skhidnii Halychyni (kinets XIX pochatok XX st.) [The role of "Prosvita" in disseminating economic knowledge in Eastern Galicia (late XIX" early $\mathrm{XX}^{\text {th }}$ centuries)]. Ukraina: kulturna spadshchyna, natsionalna svidomist, derzhavnist, issue 19, pp. 151-160 (in Ukrainian). 